\title{
Branding: Myth and reality in the hotel industry
}

Received: 30 March 2004

\section{Michael D. Olsen}

is a professor of strategic management in the hospitality industry in the Department of Hospitality and Tourism Management at Virginia Polytechnic Institute and State University, President of Michael D. Olsen and Associates (MDO) and Chairman of the Olsen Group Inc., a subsidiary of MDO, a firm providing strategic visioning leadership to the global hospitality industry. He received his PhD from Virginia Tech with a major in general business and minors in financial management and complex organisation theory.

\section{Yeasun Chung}

is a graduate student in hospitality and tourism management at Virginia Tech University in Blacksburg, Virginia, USA. Her research focus is environmental risk management and financial strategy in the hospitality industry. Prior to joining Virginia Tech University, she studied business administration at Sogang University, Korea, and worked in the financial engineering team of Korea Exchange Bank Futures Co., Ltd, as a market analyst and financial specialist for corporations and institutional investors.

\section{Nicolas Graf}

has an MBA and currently serves as a faculty member at the Ecole Hôtelière de Lausanne (EHL) in Switzerland. Nicolas is also presently pursuing his doctoral degree in hospitality and tourism management at Virginia Tech University in Blacksburg, Virginia, USA. His research and teaching focus is corporate finance and strategic management in the hospitality industry.

\section{Kyuho Lee}

is a PhD student majoring in hospitality management at Virginia Tech. Before starting the doctoral programme, he worked as a restaurant manager at Fontainebleau Hilton Resort, Miami. His research interests are the impacts of globalisation on the hospitality industry and strategic management of the global restaurant chains.

\section{Melih Madanoglu}

is presently pursuing his doctoral degree in hospitality and tourism management at Virginia Tech University in Blacksburg, Virginia, USA. Melih specialises in corporate finance and is interested in risk-return analysis, risk assessment, cost of capital and firm valuation. Prior to joining Virginia Tech he was employed as an assistant professor at Stephen F. Austin State University in Nacogdoches, Texas.

Co-authors are listed in alphabetical order, denoting an equal contribution to the paper.

\section{Abstract}

Michael D. Olsen

Department of Hospitality and Tourism Management

Pamplin College of Business

Virginia Polytechnic Institute and State University

362 Wallace Hall

Blacksburg, VA 24061-0429, USA

Tel: +1 5402318425

E-mail: olsenmd@vt.edu
The concept of the brand continues to demonstrate a strong positive presence in the minds of hotel industry executives as well as those tangentially linked to the industry. Yet when asked to define what is meant by the term 'brand', no two executives would probably be able to give identical definitions. The purpose of this paper is to address what is perceived to be the lack of a consistent understanding of the concept of the brand 


\section{Concept of brand}

Brand value claims by industry executives and academics who freely use the term in making claims as to its value. First, it proposes several additions to the probable dimensions of the brand concept. Secondly, it looks at the industry literature to ascertain what others may add to our understanding of the realities and complexities of the brand in the context of the hospitality industry. Hence, it introduces the construct of industry critical success factors and how they must be incorporated into an understanding of how a firm can achieve brand significance by how they perform on each.

\section{Keywords:}

branding, brand dimensions, critical success factors (CSFs), hotel industry

\section{INTRODUCTION}

The concept of the brand continues to demonstrate a strong positive presence in the minds of hotel industry executives as well as those tangentially linked to the industry. Yet when asked to define what is meant by the term 'brand', no two executives would probably be able to give identical definitions. The literature focusing on the context of the global hotel industry offers no consistent definition either. When the term does appear, inconsistencies abound based upon whether it is used in a marketing, accounting, franchising or management-contracting perspective. What is necessary, it appears, is a common industry framework or definition of what the concept of the brand or branding really is.

The purpose of this paper is to address what is perceived to be the lack of a consistent understanding of the concept of the brand by hotel industry executives and academics, who freely use the term in making claims as to its value with regard to customers, owners and other stakeholders. The paper will first address the contextual use of the term within the global hotel industry. Next it will provide a brief review of the literature on branding as offered in the general management and marketing literature on the topic. It will then share what is presently known about a consensus regarding the concept of the brand based upon limited industry research into the topic. Finally, it will introduce into the discussion concepts which the authors believe are important to the goal of developing dimensions that will serve as an underpinning in understanding this important construct in the international hotel industry.

In addressing these topics the paper will use the following definitions. The brand will be considered to refer to the ability of a firm to deliver on its promise, consistently (100 per cent of the time), across all business units regardless of geographical spread. The actual promise is determined by the messages the firm sends to its customers and stakeholders (those end users who buy the product, lenders, investors, hotel owners, etc) prior to or when they 
Industry practices

\section{Advantages}

purchase the products, services or a combination of both that are offered on a regular basis. Implied in this definition is the value produced by the brand for both the customer and the stakeholders of the firm.

\section{INDUSTRY CONTEXTUAL VIEW OF BRANDING}

The hotel industry has some of the world's best-known brands. Hilton is a name well known throughout the world. InterContinental was at one time also a brand with global recognition, although today this may not be so. Holiday Inn, Marriott, Choice and others have also been prominent in the USA for decades. In order to capitalise on this perceived brand recognition and differentiate themselves from their competitors, as well as to facilitate their growth strategies, the marketing executives of these companies have employed such terms as brand value, brand premium, brand equity, brand awareness and brand image as ways of trying to entice hotel owners into choosing their company over others for the purposes of management contracts and/or other approaches to meeting corporate goals for growth.

As hotel firms experienced increasing pressure from investors for growth, they created sub-brands under their primary corporate name. These sub-brands were designed to create new niche opportunities across pricing and level-of-service parameters. It is not uncommon to find today multinational chains with as many as 13 separate subbrands. In many cases, it is difficult to differentiate between the levels of service offered from one sub-brand to another and pricing is now becoming blurred among and between them. The customer, unless an experienced traveller, is probably unable to differentiate among them. This raises a perplexing question: just what is the brand? Is it a set of offerings promised by the corporate office, such as loyalty programmes, reservations systems or management development programmes? Or is it the bundles of products and services offered by each sub-brand? Perhaps it is a combination of both? Utilising the definition provided earlier, is it possible for one firm to provide a consistent level of delivery on their promises offered, 100 per cent of the time, across thousands of units in as many as 50 different geographic locations? The intuitive answer would be no; however, these claims have been and continue to be made.

The use of the brand name has been offered by firms as an advantage to entice hotel owners and investors to sign franchise agreements or management contracts. This is especially true for those firms that have pursued the dominant industry strategy, which is growth through franchising and management contracts. Such firms often make claims that their brand results in premiums in occupancy and revenue per available room (RevPAR). Such claims are difficult to substantiate, since there appears to be no scientifically proven method of actually valuing the brand, but nevertheless they are made on quite a regular basis. As will be demonstrated later in this paper, while there is a general perception 


\section{Technology}

\section{Critical success factors (CSFs)}

among industry stakeholders that for a hotel owner having a brand is better than no brand, there is almost no scientific proof in the public domain to support this thinking.

Given the advent of information technology and its convergence with the internet and e-commerce, the general consensus as to the importance and value of the brand may be put at risk. To illustrate, application service providers now make available revenue management, data warehousing and mining, property management and reservations management programs which heretofore have often been included as part of the brand package offered by multinational chains. Now, independents can purchase from a menu of items to suit their needs.

Similarly, hotel reservation systems were offered as important components of the brand. This is no longer the case, as third-party intermediaries now constitute a serious challenge to current reservation systems which no longer appear to satisfy customers' needs, especially where pricing is concerned. As a last example, quality standards are generally linked to branding claims made by firms, but today several independent third-party assessors of quality hold a threatening position in challenging claims made by hotel firms with respect to consistent quality (the brand promise). Such companies as J. D. Powers and Associates in the USA and SGS Corporation in Switzerland are examples of firms that have joined the ranks of Michelin and Mobil in rating hotel properties in terms of quality. But these new entrants into this role rely upon consumer input in addition to inspectors. This clearly dilutes the brand claims made by multinationals for consistent delivery of high standards when third parties may suggest that their information indicates that this may or may not be so.

Today, when one considers the top ten multinational hotel firms, it becomes difficult to separate the corporate statements with respect to the brand. A few examples may illustrate this point. The majority have loyalty programmes with a few making assertions to having the best, based upon surveys done by various organisations or travel-related journals. Many state that their reservation, property management and other information systems are the best. Additional claims are made to reflect human resource programmes, location advantages, marketing experience, development capabilities and execution of the brand promise. This is to be expected in a competitive environment: in today's world, these items represent critical success factors (CSFs). They are the entry barriers for those firms seeking to compete in the multinational hotel market.

The implication here is that every firm seeking to compete globally must invest in these CSFs if they expect to succeed. If the corporate brand identity is to be successful then it must reflect the superior performance of the firm on each CSF. Ideally, the firm should lead in the execution of a majority of the CSFs to be able to claim brand advantage. Otherwise, it will be constantly trying to catch up with the leader. 
Challenges

\section{Brand equity}

Shifting now from the corporate brand perspective to the individual hotel, brand identity becomes an individual property concept, generally reflecting the goods and services uniquely bundled by the management of the hotel. Beyond physical structure and appearance, such hotels exhibit unique intangible attributes that combine to create a perceived value to the customer. These may be coupled with a corporate brand identity, but this is not mandatory. It is extremely difficult, if not impossible, for a multinational to duplicate this phenomenon across multiple units in multiple locations.

These issues as outlined above create significant challenges for the international hotel industry. On the one hand, there exist corporate brands that are essentially reduced to performance on industry CSFs. These factors are the 'price of entry' to the global marketplace where intense competition among key players to achieve competitive advantage drives executives' thinking. Their performance on each factor often becomes the language used by corporate marketers to establish the brand identity. On the other hand, individual hotels are capable of creating unique intangible elements that drive individual and unique brand identity as they have the luxury of not having to duplicate these chain-wide.

The challenges faced by the industry in trying to achieve a meaningful understanding of branding reflect these bipolar dimensions. It may not be possible to solve this easily, but unless it is solved, the stakeholders in the industry will have to form their own perceptions. These perceptions will increasingly be shaped not by the statements of hotel industry executives but by others, such as third-party intermediaries. One consolation at this time is that there is also no common understanding of the brand in the literature on the topic. As will be outlined in the following section, no scientific evidence exists that solves the challenges put forth in the paper thus far. While attempts have been made in other industry contexts, none has been attempted in the international hotel industry.

\section{MARKETING PERSPECTIVE OF A BRAND}

Several researchers in the mainstream marketing area ${ }^{1}$ claim that brands are made up of marketing methods, which in turn influence consumer perceptions of products and services. Therefore, numerous studies in mainstream marketing focus on how marketing activities help a firm develop a brand.

Herremans et al. ${ }^{2}$ suggested that, among marketing activities, advertising is critical in brand building since it plays an important role in conveying the product information, and the characteristics of a product or service which are considered the main attributes of a brand in the eyes of consumers. Whereas Grassl ${ }^{3}$ pointed out that explaining brand equity by solely depending on marketing aspects might not be appropriate. Grassl ${ }^{4}$ contended that researchers who are stressing the role of marketing in determining the value of a brand tend not to make a distinction between product and brand, 


\section{Goodwill}

\section{Accounting practices}

and thus fail to draw a clear boundary between these two concepts. The author points out that marketing research should go beyond the product/brand dilemma in order to facilitate a better understanding of brand concept among investors and consumers.

\section{THE NEED FOR BRAND VALUATION - AN ACCOUNTING AND FINANCIAL VIEW}

The 1980s marked a major change in brand valuation techniques. The proliferation of merger and acquisition activities called for more robust valuation methods that could satisfy both investors and legislators. Indeed, the increasing size of 'goodwill' write-offs after mergers and acquisitions caused many accounting challenges for the acquiring companies.

In the USA, the treatment of 'goodwill' remains somewhat confusing and has generated great uncertainty among business executives. ${ }^{5}$ While the Financial Accounting Standards Board (FASB) broadly covered the intangible assets issue in Opinion No. 17 , it did not directly address the valuation of brands. Zeff and Dharan $^{6}$ deduced from Opinion No. 17 that brands developed internally must be recorded as an asset at the cost of development and maintenance. In an attempt to deal with the issue of brands and their non-determinate and dynamic life, the FASB published Statement 142 in $2001 .^{7}$ In brief, the FASB specified some classes of intangible assets, such as brands, that should not be amortised, but rather annually tested for impairment.

Until recently, in the UK and other countries using International Accounting Standards ${ }^{8}$ (IAS), when reported as 'goodwill', the difference between the price paid and the book value of the assets purchased had to be written off rapidly as required by IAS 38, often tarnishing the health of the acquirer's balance sheet. ${ }^{9}$ Starting in 1995, the International Accounting Standards Board ${ }^{10}$ (IASB) issued numerous statements attempting to address the growing concerns related to valuing brands and intangible assets. While the 20-year amortisation period required by IAS 38 remains current, the IASB issued an amended statement (IAS 22), recently updated, that provides more flexibility when accounting for brands.

The plethora of views surrounding brand valuation and the evolution of corporate and investors' needs, as well as the adjustments of accounting standards, led scholars, consulting firms and governments to develop several different brand valuation techniques. These techniques fall into four broad categories: costbased approach, market-based approach, income-based approach and mixed approach.

\section{Cost-based approach}

The cost-based approach in valuing a brand aggregates all the historical costs incurred to create, maintain and replace the brand, including research and development, market testing, continued promotion and product improvement. ${ }^{11}$ While the cost method has 
Brand valuation methods the strength of being feasible and useful for making comparisons, ${ }^{12}$ it seems to have more weaknesses when applied in real-life business situations.

One of the weaknesses is that the inability to isolate and quantify all historic expenditures for building a brand prevents the cost approach from identifying and factoring all costs directly attributable to the brand. ${ }^{13}$ Secondly, this approach directly considers neither the amount of economic benefits that can be achieved nor the time period over which they might continue, ${ }^{14}$ failing to consider the added value that can result from strategic brand management. ${ }^{15}$ Lastly, the total cost and the true brand value do not always have positive correlation. ${ }^{16}$ Some brands cannot be developed despite a huge cost expenditure, while some others can be created at a minimal cost.

Alternative models proposed that the brand's value would be the inflation-adjusted launch $\operatorname{cost}^{17}$ or the brand launching cost multiplied by its probability of success. ${ }^{18}$ But these alternative methods still fail to overcome some of the problems discussed above.

\section{Market-based approach}

The market-based method aims to assess a brand's value based on the amount for which a brand can be sold in the market. ${ }^{19}$

Subsequently, this method entails identifying the market value of a brand by comparing it to similar brand transactions (sold or licensed) that occurred in the past. One of the ways in which to identify the market value of a brand is to compare similar brands which have been sold or licensed with the subject brand. ${ }^{20}$ According to Seetharaman et al., ${ }^{21}$ it is very challenging to find similar brands which have been sold or licensed because very few brands are de facto traded or licensed. Therefore, the market-based approach has seldom been employed. ${ }^{22}$

\section{Income-based approach}

As Cravens and Guilding ${ }^{23}$ maintain, by looking at the income that can be attributed to the brand, one can avoid the majority of the shortcomings that are associated with the cost-based approach. The first method the authors propose is called 'brand price premium', which is estimated by comparing a branded product to an unbranded (generic) product. In this method, the future expected brand earnings are estimated and then discounted back to their present value using a discount rate that factors in the risks associated with this stream.

Another way of looking at it is the value of licensing out the brand to other firms/entrepreneurs. In other words, the brand is treated as an asset that is literally 'leased' through the life of the franchise contract. Then, by looking at the amount of the royalty fees that will be paid in the foreseeable future, one can attempt to estimate the value of a brand. This method is called the 'royalty 


\section{An alternative view}

\section{An example}

relief method' (RRM). ${ }^{24}$ Abratt and Bick ${ }^{25}$ state that two rules of thumb have emerged in the use of the RRM. The first rule denotes that the royalty rate should comprise 25 per cent of the net profit. On the other hand, the second rule suggests that the royalty should be 5 per cent of turnover.

\section{Mixed approach}

As a result of the many pitfalls related to the three previously discussed approaches, mixed models have emerged. The most widely cited model was developed and introduced in 1987 by the Interbrand Group. ${ }^{26}$ The methodology used by the firm has been succinctly described by several researchers ${ }^{27}$ as using a brandearnings multiplier to compute the brand equity; the multiplier being worked out via the calculation of six factors.

Motameni and Shahrokhi ${ }^{28}$ presented another version of a mixed valuation model. In their study, they suggest that all previous models had presented relevant factors but those models did so from different perspectives. Thus, they suggested that a more global view, including many of the variables recommended by previous authors, should be taken. Their model is established around three key dimensions, namely the customer base potency, the competitive potency and the global potency of the brand. The weight of each dimension is obtained through management or customers' survey, resulting in an overall brand strength score.

Recognising the ever-increasing importance of intangible assets, the government of $\mathrm{Japan}^{29}$ commissioned a research group to address the quest for the brand and its value. In 2002 the research team published The Report of the Committee on Brand Valuation and proposed a new quantitative valuation model. The brand valuation model presented in the Japanese study is mainly based upon the income-based approach, and adopts the expected cash flow method to determine the monetary gain associated with the brand as well as its degree of risk. In this methodology, the past accounting figures are expected to incorporate the risk materialised in the past, and thus the aggregate average of historical profits is considered as the most robust starting point for future expectations. The issue of time, or the life of the brand, is resolved by assuming that the life of the corporate brand corresponds to the life of the company itself.

The model is constructed around three dimensions that represent the advantages created by brands: the prestige and ability to charge a price premium; the loyalty and the stability of future sales; and the expansion capabilities of the brand, both in scale and in scope. The model developed by the Japanese research team is certainly the most exhaustive and mathematically sound model presented to date. But as acknowledged by the authors, it is bounded by the current accounting practices. While the research team tried to validate the model using time series regressions, and refined the model based on those findings, the question of the validity of the formula and method remains 


\section{Shortcomings of the methods}

unanswered. This issue makes the overall model questionable and certainly not specific to any industry.

\section{Synthesis of brand valuation methods}

The existing discrepancy between identifiable assets and the price paid for acquired companies led legislators, scholars and consulting firms to seek methods that will enable them to value brands in more relevant and dynamic ways. In the early days, the experts investigating this issue strictly adhered to the prevalent accounting standards and developed methods that focused primarily on reported figures, but failed to address the relevancy issue behind corporate needs. For example, the cost approach falls short in tackling two specific cases: where the failure of a brand would imply that its value vanishes, while indeed the brand development cost still remains on the balance sheet; and when a brand has been developed at a cost not representing the true value delivered.

The other two methods also demonstrate some drawbacks and fail to satisfy the needs of businesses. The market-based approach, similarly to the sales comparison approach in real estate, is weak in that it assumes a liquid market for buyers and sellers, and that brands can be compared easily. For one thing, brands are not traded frequently enough so that one can obtain meaningful data, and secondly, the inimitability intrinsic to the brand makes any comparison risky.

The third approach, the income-based model, emerged as a more contemporary method that embraces some of the crucial aspects of business firms by taking a future-oriented perspective that is geared towards the value-adding capabilities of the brand. But this method fails to realise the complexity of assessing the future streams of cash flows associated with the brand and the risk inherent to its evolution. The price premium technique considers cases where the industry is primarily made up of few products and companies that are pure players. In more complex and dynamic industries, where products and services are numerous, the key to success lies in finding a relevant and reliable benchmark product to compare with the brand under investigation. In addition, the progression of prices through time between branded and unbranded products makes the computation hazardous if the gap between branded and generic products widens and narrows over time.

The second technique, based on royalty fees paid for the product, is undermined by the various assumptions underlying this method. First, it assumes that royalty fees are paid for the sole use of the brand and no other attributes are considered. Secondly, the relationship between the level of royalty fees and the value of the brand may not be proportional (ie high royalty fee and low brand value). This leads to the question of whether an increase in royalty fees directly implies a similar increase in the overall value of the brand. In addition, this technique would yield inconclusive results when a company does not franchise or lease its brand. 


\section{Exploratory findings}

The latest development in the brand valuation arena adopted a mixed approach in order to improve accuracy, relevancy and practicality, while simultaneously attempting to minimise the shortcomings that surfaced in the previous works. In this method, one of the major drawbacks is the issue of validity of the measures and data themselves. The Japanese government has developed one of the most exhaustive models, to date, that captures the dimensions of the brand. While the model is robust in terms of its quantitative presentation, it could not overcome the challenges posed by the accounting standards and the industry-specific drivers of cash flows. For example, when considering the hospitality industry, the loyalty driver of the model could result in a relatively low ratio in the case of a wide variation of occupancy due to environmental events, and thus exert a downward pressure on the overall brand value of hospitality companies.

\section{SOME INITIAL ATTEMPTS AT UNDERSTANDING THE BRAND}

As pointed out thus far, the international hotel industry has used a wide variety of terms and dimensions to characterise the brand, but has achieved no industry-wide consensus as to what the term really means. In addition, the general trade and scholarly literature has proposed several approaches. Despite these efforts, the term still remains elusive, perhaps due to the complexity of the construct itself. But given the growing pressure to account for the intangible value of the firm (often described as the difference between book and market value of the firm), the need to address this elusiveness grows daily.

In an attempt to resolve the lack of a uniform understanding of the concept of the brand in the international hotel industry, the International Hotel Investment Council, in cooperation with the organisers of the International Hotel Investment Forum in Berlin in March 2004, surveyed advanced registrants to assess their views on certain dimensions of the brand within the international hotel industry (this step is part of a broader effort to address the brand definition problem). A total of 311 participants responded, and the results are displayed in Table 1. As illustrated, the largest group of respondents fell into the consultant/analyst category, followed by the operator category - together they represented one-third of the total participants.

Each respondent was asked to react to six statements about the brand. These statements were crafted based upon the review of literature summarised above, but were then subjected to an industry contextual review to try to reflect industry terminology. Executives familiar with the branding concept within the international hotel industry provided the terminology for this purpose. The statements and mean score responses are presented in Table 2. Participants were asked to agree or disagree on a five-point scale with the statement provided (5 representing a strong agreement, and 1 a strong disagreement). The results represent the perceptions of the 
Table I: Participant profiles

\begin{tabular}{lcr}
\hline Participant category & Count & $\%$ \\
\hline Hotel/resort operator & 43 & 13.8 \\
Bank/lender & 20 & 6.4 \\
Financial adviser & 22 & 7.1 \\
Real estate agent/surveyor & 27 & 8.7 \\
Lawyer & 20 & 6.4 \\
Accountant & 9 & 2.9 \\
Architect/designer & 17 & 5.5 \\
Consultant/analyst & 67 & 21.5 \\
Tourism/government official & 4 & 1.3 \\
Timeshare operator & 3 & 1.0 \\
Travel agent/tour operator & 4 & 1.3 \\
Hotel developer/builder & 11 & 3.5 \\
Supplier & 7 & 2.3 \\
Education & 3 & 1.0 \\
Other & 16 & 5.1 \\
& 311 & 100.0 \\
Total & 311 & \\
\hline
\end{tabular}

respondents. The mean scores are ranked from highest to lowest. As can be seen, access to capital was perceived to be the primary benefit of the brand. The ability of the brand to support growth also ranked high. As further analysis of the table illustrates, all the means suggest that respondents agree with each statement and, by extension, suggest that they accept each as a probable dimension of the concept of the brand.

While the mean scores represent the perceptions of the participants, what is important for the purposes of this paper is that six dimensions have emerged that help to begin to shape an initial understanding of what the concept of the brand is within the international hotel industry. Much work still needs to be done to develop a more complete and exhaustive understanding of this construct before these dimensions become unequivocal. They do, however, represent the commencement of this effort to do so.

\section{CSFs}

As can be assessed from the information presented thus far, the generic as well as industry literature has failed to reach a consensus as to a common understanding of what the brand is and its impact. Although it is generally perceived to be of value by industry stakeholders, the literature presents no strong scientific evidence to

Table 2: Ranking of brand statements

\begin{tabular}{llr}
\hline Brand statements & Mean* \\
\hline 1 & Brands have greater access to capital. & 4.14 \\
2 & Branded hotel companies and hotels grow faster than unbranded equivalents. & 4.04 \\
3 & Branded hotel companies are managed in a more rational manner than unbranded equivalents. & 3.57 \\
4 & Brands perform better than unbranded equivalents. & 3.56 \\
5 & The capacity of a brand to reduce costs is a function of the size of its rooms' portfolio. & 3.49 \\
6 & The brand ensures longer economic life to assets. & 3.42 \\
7 & The capacity of a brand to generate demand is a function of the size of its rooms' portfolio. & 3.33 \\
\hline
\end{tabular}

Note: * 1 = strongly disagree, 5 = strongly agree 


\section{Determining CSFs}

support these perceptions. Given this state of uncertainty and what the authors consider to be rather invalid and unreliable attempts to accomplish this goal, this paper will propose possible dimensions in the subsections below to be considered in attempting to achieve a more universal understanding of the concept; ones which the authors believe reflect the realities of the brand in today's marketplace.

Referenced earlier, CSFs represent the essential competitive methods making up a firm's strategy that must be in place if they are to compete globally - in other words, they represent the barriers or costs of entry into this competitive arena. These elements represent in many cases significant investments by multinational hotel companies for which the investor or hotel owner expects returns that add value above the cost of capital. Therefore, management must make strategic investment decisions regarding each CSF with respect to how competitive they want to be. Since these are common industry practices it can be assumed that a firm's performance against competition can be considered a part of its brand value. More importantly, the longer a firm is able to sustain its performance on each CSF, especially if it can maintain an industry leadership position, the more lasting will be its brand value.

To illustrate this point, Table 3 provides a partial list of CSFs as determined from a content analysis of the annual reports of leading multinational hotel firms, industry trade literature, marketing materials related to franchising and management contracts and scholarly literature in the field. These factors simply reflect what the industry is stating as important for long-term survival. Many firms claim to have leadership in one or more of the CSFs. If this is the case then one of the major dimensions of the brand, within the industry context, must be how well a firm is performing over time on each factor. It is intuitively obvious that if a firm is able to assume industry leadership across a significant percentage of these CSFs then they can claim brand leadership and thus value created by the brand.

The list of CSFs in Table 3 is limited. There are of course others, depending on the levels of service provided and the particular

Table 3: Industry CSFs 


\section{Proposed variables}

location issues that may apply. The main proposition here is that once one has a valid and reliable industry-wide list of CSFs, and they become part of the brand definition used by multinationals, one has added to the list of dimensions shaping an understanding of the brand. Additionally, as firms invest in these CSFs, one can assume they are seeking to achieve competitive advantage in order to equate this advantage with added value provided by their performance on each.

\section{Performance indicators}

As stated earlier, hotel companies are prone to making sweeping generalisations about the value of their brand without scientific evidence to back them up. This is in part due to the lack of ways of measuring the competitive methods which are linked to brand value. It may also be that such evidence is not in the public domain, and thus one is unable to assess the validity of such claims. Therefore, in an effort to avoid the continued use of these generalisations, the list of performance variables outlined in Table 4 suggests a more rigorous look at claims of brand leadership. These items should be viewed as additional statements designed to build more valid dimensions to be used in accomplishing the goal of better understanding the brand and assessing its overall value contributions to stakeholders.

Each of the performance metrics listed in Table 4 reflects the context of the multinational hotel industry. They are key variables which are far removed from the standard univariate industry metric

Table 4: Key performance measures of the brand in the international hotel industry

\begin{tabular}{|c|c|}
\hline Key measure & Description \\
\hline Asset mix portfolio & $\begin{array}{l}\text { Age of assets versus capital required to keep them } \\
\text { productive? }\end{array}$ \\
\hline Brand sincerity ratio & $\begin{array}{l}\text { What percentage of hotels in the portfolio currently } \\
\text { meet the brand standards or promise? }\end{array}$ \\
\hline The ageing factor of management contracts & $\begin{array}{l}\text { Is the current length of the contract increasing or } \\
\text { decreasing over a specific trend line period? }\end{array}$ \\
\hline Equity participation curve & $\begin{array}{l}\text { Are hotel firms required to inject greater levels of equity } \\
\text { to maintain growth and brand equity? }\end{array}$ \\
\hline Brand dilution variable & $\begin{array}{l}\text { How many new corporate sub-brands must be } \\
\text { introduced in order to maintain growth? }\end{array}$ \\
\hline $\begin{array}{l}\text { Ratio of free cash flow generation capability per asset } \\
\text { age }\end{array}$ & $\begin{array}{l}\text { Are hotels able to maintain free cash flow generation to } \\
\text { owners' equity as the asset ages? }\end{array}$ \\
\hline $\begin{array}{l}\text { Ratio of firm's resources devoted to maintain the } \\
\text { firm's position on CSFs }\end{array}$ & $\begin{array}{l}\text { What is the policy of the firm with respect to maintaining } \\
\text { continuous investment in CSFs? }\end{array}$ \\
\hline Ratio of free cash flow generation based upon the & What percentage of the firm's free cash flow comes from \\
\hline risk factors associated with hotel locations & $\begin{array}{l}\text { locations that are considered high risk with respect to } \\
\text { country location? }\end{array}$ \\
\hline Foreign propensity ratio & $\begin{array}{l}\text { What percentage of the firm's hotels reflect geographical } \\
\text { dispersion from the home nation headquarters and how } \\
\text { is oversight provided? }\end{array}$ \\
\hline $\begin{array}{l}\text { Complexity of modes of entry into foreign or new } \\
\text { markets }\end{array}$ & $\begin{array}{l}\text { Are the deals becoming more complex with guarantees } \\
\text { and are other deliverables having to be built into } \\
\text { management contracts or franchise agreements? }\end{array}$ \\
\hline $\begin{array}{l}\text { Reliance upon legacy properties for free cash flow } \\
\text { generation }\end{array}$ & $\begin{array}{l}\text { What percentage of the corporate free cash flow is } \\
\text { generated by the legacy properties in the portfolio and } \\
\text { the trend behind these cash flows? }\end{array}$ \\
\hline
\end{tabular}




\section{Assessment
of metrics \\ Assessment
of metrics}

\section{Remarks}

.

of RevPAR, which has been promoted for years as the key measure of hotel and brand performance. There are many problems with the use of a single metric such as RevPAR, due simply to the complexity of the environment in which hotel companies operate, suggesting that one measure cannot possibly capture hotel performance. To generalise from one metric is full of probable errors and is certainly not scientific. There are also problems with the validity and reliability of this measure. Thus, the metrics listed in Table 4 represent alternatives to the simplistic measures presently employed and offer a more substantive look at the construct of the brand.

Investors seek to maximise their risk-return relationships. The perception of the brand is that it helps to accomplish this objective. Risk in this case refers to the variance in the cash flow streams of the firm. Management are obliged to seek some stability in these cash flow streams. It is the proposition here that the metrics provided in Table 4 are helpful in understanding the stability of the cash flows going forward. Furthermore, it is suggested that unless management of multinationals are working on improving their performance on each metric, their ability to sustain growth in cash flow with little variance will diminish. Any increase in cash flow variance will then result in higher debt and equity premiums imposed by lenders and investors. These scenarios are not what executives desire.

The point in introducing these metrics is to support the contention that the brand is a complex yet intangible phenomenon. Heretofore, the concept has been simplified by the limited body of scientific knowledge on this topic. Because of this limitation and the use of primitive metrics such as RevPAR, the concept, and the statements made by executives regarding brand value, have little credibility today. If this is to change, greater effort must be made towards ensuring a more scientific approach to defining the concept of the brand and its value.

\section{SOME CONCLUDING THOUGHTS}

The challenges posed in this paper do not lend themselves to easy resolution. First, the context of the industry, from the perspective addressed here in this paper, is that it is a player in the global capital market scheme when it comes to competing for capital. As such, executives have been forced blindly to follow a growth strategy, regardless of the probable long-term risks associated with this approach, just to meet the return expectations of the markets. Few executives have the courage to say that they are endorsing a non-growth strategy. Their boards would invite them to submit their resignations if they did. They seem lost in creating other strategies that create value. This pressure for growth has contributed to the emergence of branding as a way of introducing new hotel products into market niches. This pressure for growth cannot be expected to subside, thus ultimately executives will have 


\section{Synthesis}

to find ways of demonstrating growth in value without continuing to develop new hotels or sub-brands. The question is: will improving an understanding of the dimensions making up the brand help to accomplish this goal?

The literature on branding, whether in generic management or marketing literature or in industry-contextual literature, leaves much to be desired. This underscores the difficulty of resolving this perplexing issue. It appears that the topic is too complex for any one specific discipline to come to the rescue. It really requires a more multidisciplinary effort. This implies more complex models; but in order to perform the analysis required by them, industry must cooperate with valid and reliable data. Thus far, these are not forthcoming. Consequently, the literature appears prostrate in giving help in this matter.

This paper has proposed several additions to the probable dimensions of the brand concept. Some of them have resulted through preliminary research from a small sample of those registered for the International Hotel Investment Forum in Berlin in March 2004. Secondly, it has looked at the industry literature to ascertain other possible dimensions that may help to address the realities and complexities of the industry. It has introduced the construct of industry CSFs and how they must be incorporated into an understanding of how a firm can achieve brand identity or value by how well they perform on each. While they are necessary to enter into the international hotel environment, it is essential that they be performed well and preferably at an industry-leading level to ensure sustainable brand and competitive advantage.

It has also proposed new metrics, with the suggestion that they must be combined into more complex models that reflect how they affect risk and subsequent costs of debt and equity. The literature on branding seems to have ignored these key concepts of financial management and, along with the absence of reference to CSFs, seems lacking a more rational and scientific basis for understanding the construct of the brand. These metrics call for a move towards a more comprehensive view of measuring the brand, away from a reliance on accounting efforts alone.

The authors strongly believe that branding issues call for investments and should be considered using the same types of tools required for any financial investment decision. To do this one needs more reliable and valid sources of data, which the industry has been loath to produce. Yet without these, the confidence that stakeholders in the industry have with regard to management claims of brand value will fail to be enhanced. This failure will no doubt result in market capitalisations based upon the aggregated discounted cash flows of management contracts, franchise royalties and owned properties ignoring the investments made by firms to enhance their brand. This is not a satisfactory outcome for the industry.

It should be noted that current brand concepts and valuation 
methods in existing literature do not reflect the dimensions proposed here. The argument is that generalised methods do not apply to industry-contextual needs. The authors strongly advocate that greater scientific efforts be directed at the development of dimensions that can then be used to address this complex issue in the international hotel industry context. To do this, a greater level of objectivity and even maturity must be demonstrated by industry leaders who are committed to strengthening the body of knowledge devoted to this important industry.

\section{References}

1. Pitta, D. A. and Katsanis, L. P. (1995) 'Understanding brand equity for successful brand extension', Journal of Consumer Marketing, Vol. 12, No. 4, pp. 51-64; Keller, K. L. (2000) 'The brand report card', Harvard Business Review, Vol. 78, No. 1, pp. 147-157; Aufreiter, N. A., Elzinga, D. and Gordon, J. W. (2003) 'Better branding', The McKinsey Quarterly, Vol. 4, pp. 29-39.

2. Herremans, I. M., Ryans, J. K. and Aggarwal, R. (2000) 'Linking advertising and brand value', Business Horizons, Vol. 68, No. 1, pp. 19-26.

3. Grassl, W. (1999) 'The reality of brands: Towards ontology of marketing', American Journal of Economics and Sociology, Vol. 58, No. 2, pp. 313-360.

4. Ibid.

5. Seetharaman, A., Nadzir, Z. A. B. M. and Gunalan, S. (2001) 'A conceptual study on brand valuation', Journal of Product and Brand Management, Vol. 10, No. 4, pp. 243256.

6. Zeff, S. A. and Dharan, B. G. (1997) Readings and Notes on Financial Accounting, 5th edn, McGraw-Hill, Maidenhead, England.

7. Financial Accounting Standards Board (2001) Goodwill and Other Intangible Assets, Statement No. 142, available from www.fasb.org/st/summary/stsum142.shtml.

8. International Accounting Standards Board (2004) IAS Standards, available from http:// iasb.org.

9. Murphy, J. (1990) 'Assessing the value of brands', Long Range Planning, Vol. 23, No. 3, pp. 23-29.

10. International Accounting Standards Board, ref. 8 above.

11. Keller, K. L. (1998) Strategic Brand Management: Building, Measuring and Managing Brand Equity, Prentice-Hall, Upper Saddle River, NJ; Neils, M. E. (2002) 'Are your brand-building efforts paying off?', available from www.absolutebrand.com/ RESEARCH/Default.asp?dismode $=$ article\&artid $=113$; Hart, S. and Roslender, R. (2002) 'Distinguishing marques: Management accounting for brands', available from www.corporateidentityonline.com/value $3 . \mathrm{htm}$.

12. Abratt, R. and Bick, G. (2003) 'Valuing brands and brand equity: Methods and processes', available from www.huizenga.nova.edu/jame/valuing.htm; Neils, ibid.

13. Abratt and Bick, ibid.; Neils, ref. 11 above.

14. Aaker, D. A. (1991) Managing Brand Equity: Capitalizing on the Value of a Brand Name, Free Press, New York, NY; Keller, ref. 11 above; Harris, J. E. (2002) 'Valuing intangible assets: A primer', available from www.bizval.com/Publications/PrintableVersion/ Mercer\%20Capital\%20MFN\%202002-09.pdf.

15. Hart and Roslender, ref. 11 above.

16. Woodward, C. (2003) Valuation of Intellectual Property, PricewaterhouseCoopers, London, England.

17. Reilly, R. F. and Schweihs, R. P. (1999) Valuing Intangible Assets, McGraw-Hill, New York, NY.

18. Aaker, ref. 14 above.

19. Government of Japan (2002) The Report of the Committee on Brand Valuation, Ministry of Economy, Trade and Industry, Tokyo, Japan.

20. Seetharaman, et al., ref. 5 above. 
21. Ibid.

22. Murphy, ref. 9 above; Seetharaman et al., ref. 5 above.

23. Cravens, K. and Guilding, C. (1999) 'Strategic brand valuation: A cross-functional perspective', Business Horizons, July-August, pp. 53-62.

24. Aaker, ref. 14 above.

25. Abratt and Bick, ref. 12 above.

26. Murphy, J. (ed.) (1989) Brand Valuation: A True and Fair View, Hutchinson, London, England.

27. Wentz, L. and Martin, G. (1989) 'How experts value brands', Advertising Age, 16 January, p. 24; Murphy, ref. 9 above; Kapferer, J. N. (1992) Strategic Brand Management: New Approach to Creating and Evaluating Brand Equity, Free Press, New York, NY.

28. Motameni, R. and Shahrokhi, M. (1998) 'Brand equity valuation: A global perspective', Journal of Product and Brand Management, Vol. 7, No. 4, pp. 275-290.

29. Government of Japan, ref. 19 above. 